\title{
Alkoxy Radical Bond Scissions Explain the Anomalously Low Secondary Organic Aerosol and Organonitrate Yields From $\alpha$-Pinene $+\mathrm{NO}_{3}$
}

Theo Kurtén, ${ }^{*}{ }^{\dagger \oplus}$ Kristian H. Møller, ${ }^{\ddagger}$ Tran B. Nguyen, ${ }^{\S}$ Rebecca H. Schwantes, ${ }^{\Perp} \gg$ Pawel K. Misztal, ${ }^{\perp}$

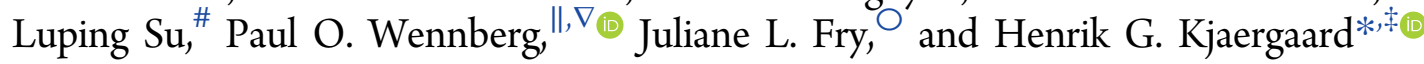

${ }^{\dagger}$ Department of Chemistry, University of Helsinki, P.O. Box 55, FI-00014 Helsinki, Finland

${ }^{\ddagger}$ Department of Chemistry, University of Copenhagen, Universitetsparken 5, DK-2100 Copenhagen $\varnothing$, Denmark

${ }^{\S}$ Department of Environmental Toxicology, University of California - Davis, Davis, California 95616, United States

"Division of Geological and Planetary Sciences, California Institute of Technology, 1200 East California Blvd, Pasadena, California 91125, United States

${ }^{\perp}$ Department of Environmental Science, Policy, \& Management, University of California - Berkeley, Berkeley, California 94720, United States

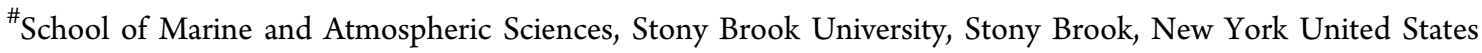

${ }^{\nabla}$ Division of Engineering and Applied Science, California Institute of Technology, 1200 East California Blvd, Pasadena, California 91125, United States

${ }^{\circ}$ Chemistry Department, Reed College, Portland, Oregon 97202, United States

Supporting Information

ABSTRACT: Oxidation of monoterpenes $\left(\mathrm{C}_{10} \mathrm{H}_{16}\right)$ by nitrate radicals $\left(\mathrm{NO}_{3}\right)$ constitutes an important source of atmospheric secondary organic aerosol (SOA) and organonitrates. However, knowledge of the mechanisms of their formation is incomplete and differences in yields between similar monoterpenes are poorly understood. In particular, yields of SOA and organonitrates from $\alpha$-pinene $+\mathrm{NO}_{3}$ are low, while those from $\Delta^{3}$ carene $+\mathrm{NO}_{3}$ are high. Using computational methods, we suggest that bond scission of the nitrooxy alkoxy radicals from $\Delta^{3}$-carene lead to the formation of reactive keto-nitrooxy-alkyl radicals, which retain the nitrooxy moiety and can undergo further reactions to form SOA. By contrast, bond scissions of the nitrooxy alkoxy radicals from $\alpha$-pinene lead almost exclusively to the formation of the relatively unreactive and volatile product pinonaldehyde $\left(\mathrm{C}_{10} \mathrm{H}_{16} \mathrm{O}_{2}\right)$, thereby limiting organonitrate and SOA formation. This hypothesis is supported by laboratory experiments that quantify products of the reaction of $\alpha$-pinene $+\mathrm{NO}_{3}$ under atmospherically relevant conditions.

$\Delta^{3}$-carene $+\mathrm{NO}_{3}$
$\mathrm{P}$ lants emit enormous quantities of highly reactive biogenic alkenes to the atmosphere. Monoterpenes $\left(\mathrm{C}_{10} \mathrm{H}_{16}\right){ }^{1}$ contribute approximately $11 \%$ of these emissions, with $\alpha$ pinene as the dominant (35\%) contributor. ${ }^{2}$ The subsequent oxidation of these compounds in the atmosphere impacts both aerosol and ozone levels.

Atmospheric aerosol particles play a key role in regulating our climate, ${ }^{3}$ and are responsible for most air pollution-related mortality. ${ }^{4}$ A large fraction of these particles consists of secondary organic aerosol (SOA) material formed by oxidation of large organic molecules such as monoterpenes. It is this chemistry, for example, that is responsible for the haze that makes the US Smoky Mountains "smoky". Despite its importance, the mechanisms for SOA formation from biogenically produced alkenes are poorly understood.

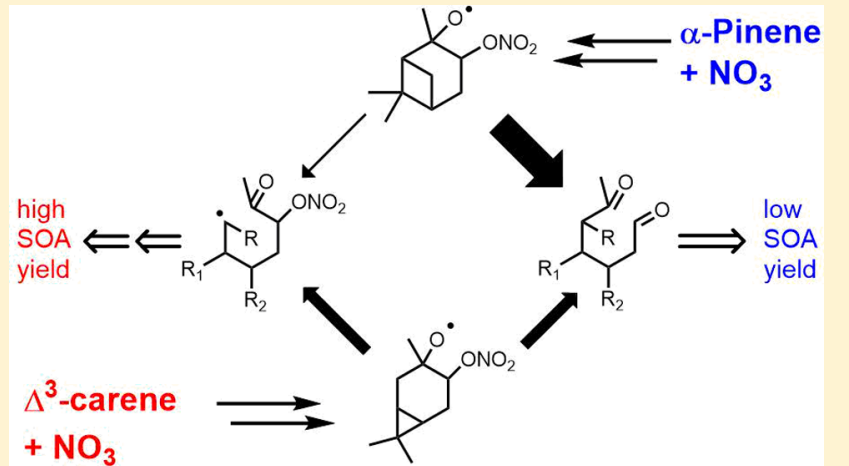
Ozone is a significant component of photochemical smog and is associated with pulmonary impacts in humans as well as being an antagonist for plants. Formation of ozone occurs in the troposphere via the oxidation of organic hydrocarbons in the presence of nitric oxide (NO). The highly reactive monoterpenes can contribute significantly to this process. However, oxidation of these biogenic compounds can also reduce ozone formation via production of organonitrates that serves to reduce the level of rapidly interconverting nitrogen oxide free radicals $\left(\mathrm{NO}_{x}\right)$ here defined as the sum of $\mathrm{NO}, \mathrm{NO}_{2}$,

Received: April 28, 2017

Accepted: June 6, 2017

Published: June 6, 2017 
Scheme 1. Reaction Pathways for the $\alpha$-Pinene $+\mathrm{NO}_{3}$ System ${ }^{a}$

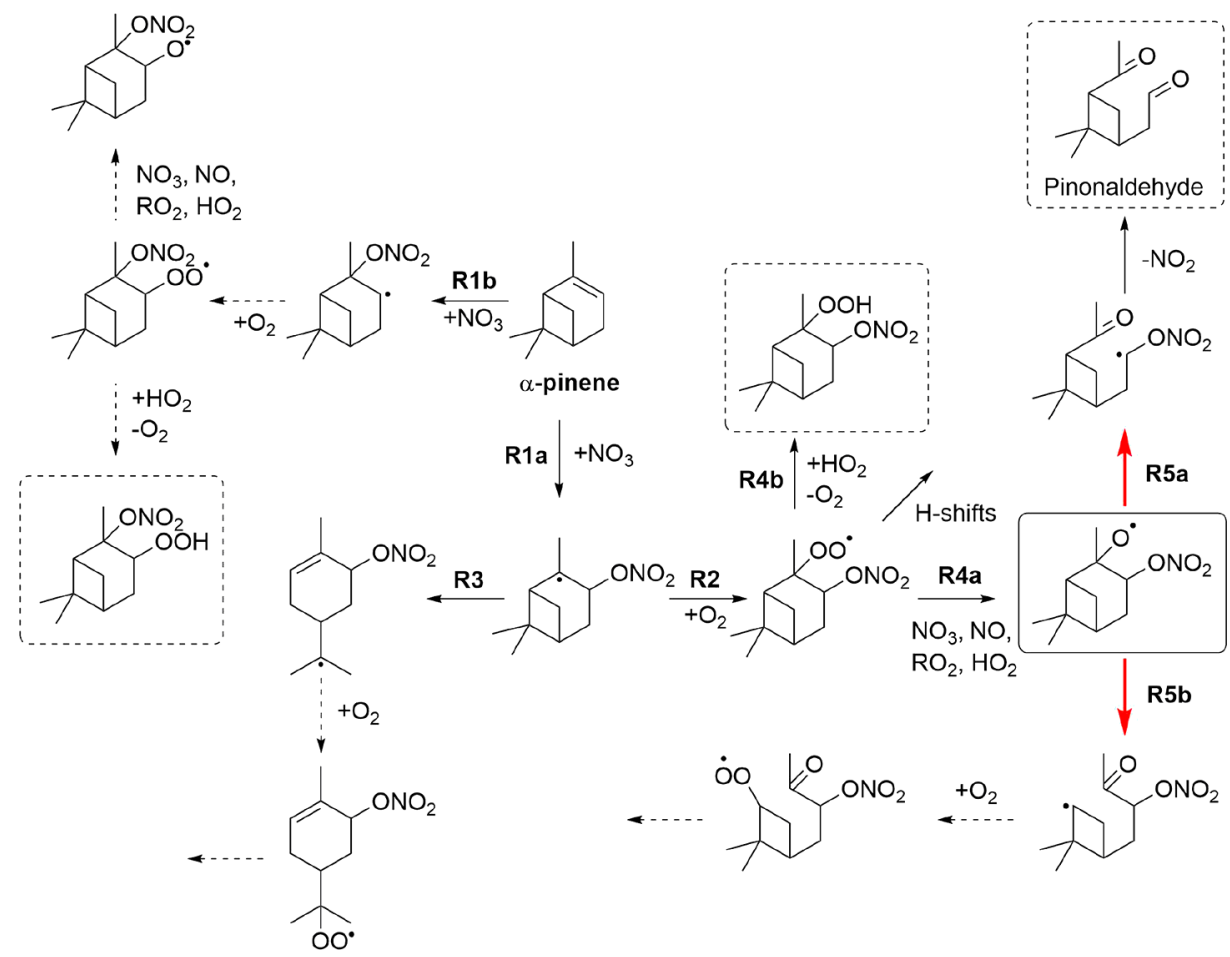

${ }^{a}$ Reactions studied here are labeled, while likely subsequent reactions not investigated in this study are indicated by dashed arrows. To evaluate the calculated branching ratios, the yields of the hydroperoxy nitrates and pinonaldehyde (shown in dashed boxes) are quantified experimentally. The key $\beta$-nitrooxy-alkoxy radical is shown in the solid box with the bifurcating reactions highlighted with red arrows.

and $\mathrm{NO}_{3}$. The impact on $\mathrm{NO}$, and thus ozone formation, therefore depends on the yield of the organonitrates and whether during their subsequent degradation the $\mathrm{NO}_{x}$ is recycled. ${ }^{6}$

Recent global modeling studies of organic aerosol ${ }^{7-9}$ suggest that a large contribution to SOA production arises from the oxidation of biogenic organic compounds by the nitrate radical $\left(\mathrm{NO}_{3}\right)$. This contribution is potentially larger than that following their oxidation by ozone or $\mathrm{OH} .{ }^{10}$ Though typically thought of as a nighttime process, $\mathrm{NO}_{3}$ oxidation has recently been shown to play a role also during the day. ${ }^{11,12}$ In addition, field analyses of organonitrate diurnal variation ${ }^{13-16}$ illustrate that $\mathrm{NO}_{3}$ oxidation chemistry is a major pathway for the production of organonitrates. ${ }^{17}$ Depending on their subsequent photochemistry, these nitrates constitute a large $\mathrm{NO}_{x}$ reservoir or sink. Improved understanding of the mechanistic basis for the differing yields of SOA and organonitrates from oxidation of biogenic compounds following their oxidation by $\mathrm{NO}_{3}$ is thus essential.

SOA levels are typically underestimated by current atmospheric chemistry models. ${ }^{18,19}$ Recent research $^{20-22}$ indicates that peroxy radical $\left(\mathrm{RO}_{2}\right)$ hydrogen shift rearrangements (H-shifts)-particularly important in monoterpene chemistry-may be responsible for part of the underestimate. According to these studies, sequential $\mathrm{RO}_{2} \mathrm{H}$-shifts and $\mathrm{O}_{2}$ addition reactions (often termed autoxidation) rapidly lead to highly oxidized multifunctional products (HOMs) that end up in the aerosol phase via equilibrium partitioning. The prerequisite for atmospheric autoxidation is that the initial oxidant-hydrocarbon reaction leads to an $\mathrm{RO}_{2}$ radical that can access $\mathrm{C}-\mathrm{H}$ bonds weak enough to allow $\mathrm{H}$-shifts to compete with bimolecular reactions. ${ }^{23-25}$
Much research on monoterpene oxidation in the context of SOA and organonitrate formation has focused on $\alpha$-pinene, as it accounts for about $35 \%$ of total global monoterpene emissions. ${ }^{2,26}$ The organonitrate and SOA yield varies with both the monoterpene and the oxidant. These variations are reasonably well understood for $\mathrm{OH}$ - and $\mathrm{O}_{3}$-initiated oxidation. For example, exocyclic alkenes often have lower HOM or SOA yields from ozonolysis than analogous endocyclic alkenes. ${ }^{27}$ The variations in yields in the $\mathrm{NO}_{3}$-initiated oxidation of different monoterpenes are less well understood. For example, the $\mathrm{NO}_{3}+\alpha$-pinene reaction has a low organonitrate yield and leads to little or no SOA formation. ${ }^{28-31}$ By contrast, the yields of both organonitrates and $\mathrm{SOA}$ from $\mathrm{NO}_{3}$-initiated oxidation of every other monoterpene studied are considerably higher. ${ }^{10}$ For example, both the organonitrate and SOA yields from $\Delta^{3}$ carene have been measured to be larger than $50 \%$, despite the similar structures of $\Delta^{3}$-carene and $\alpha$-pinene (see Schemes 1 and 2). ${ }^{28}$ Previous laboratory studies of the reaction of $\alpha$ pinene $+\mathrm{NO}_{3}$ have found high yields of carbonyls and low yields of organonitrates. ${ }^{29}$ The opposite has been shown to apply to the $\Delta^{3}$-carene $+\mathrm{NO}_{3}$ reaction. ${ }^{10,28}$

Here we show that the key to understanding the disparate organonitrate and SOA yields in these very similar monoterpenes arises from a bifurcation in the fragmentation of the $\beta$ nitrooxy-alkoxy radicals (nitrooxy and alkoxy groups on neighboring carbon atoms) produced following addition of $\mathrm{NO}_{3}$. In the case of $\alpha$-pinene, scission of the bond between these groups releases $\mathrm{NO}_{2}$ and yields the highly volatile pinonaldehyde. In $\Delta^{3}$-carene, by contrast, this bond is more likely to remain intact, yielding a nitrooxy-peroxy radical that is able to undergo further reactions. We use computational methods (see section S1 in the Supporting Information (SI) for 
Scheme 2. Reaction Pathways for the $\Delta^{3}$-Carene $+\mathrm{NO}_{3}$ System $^{a}$

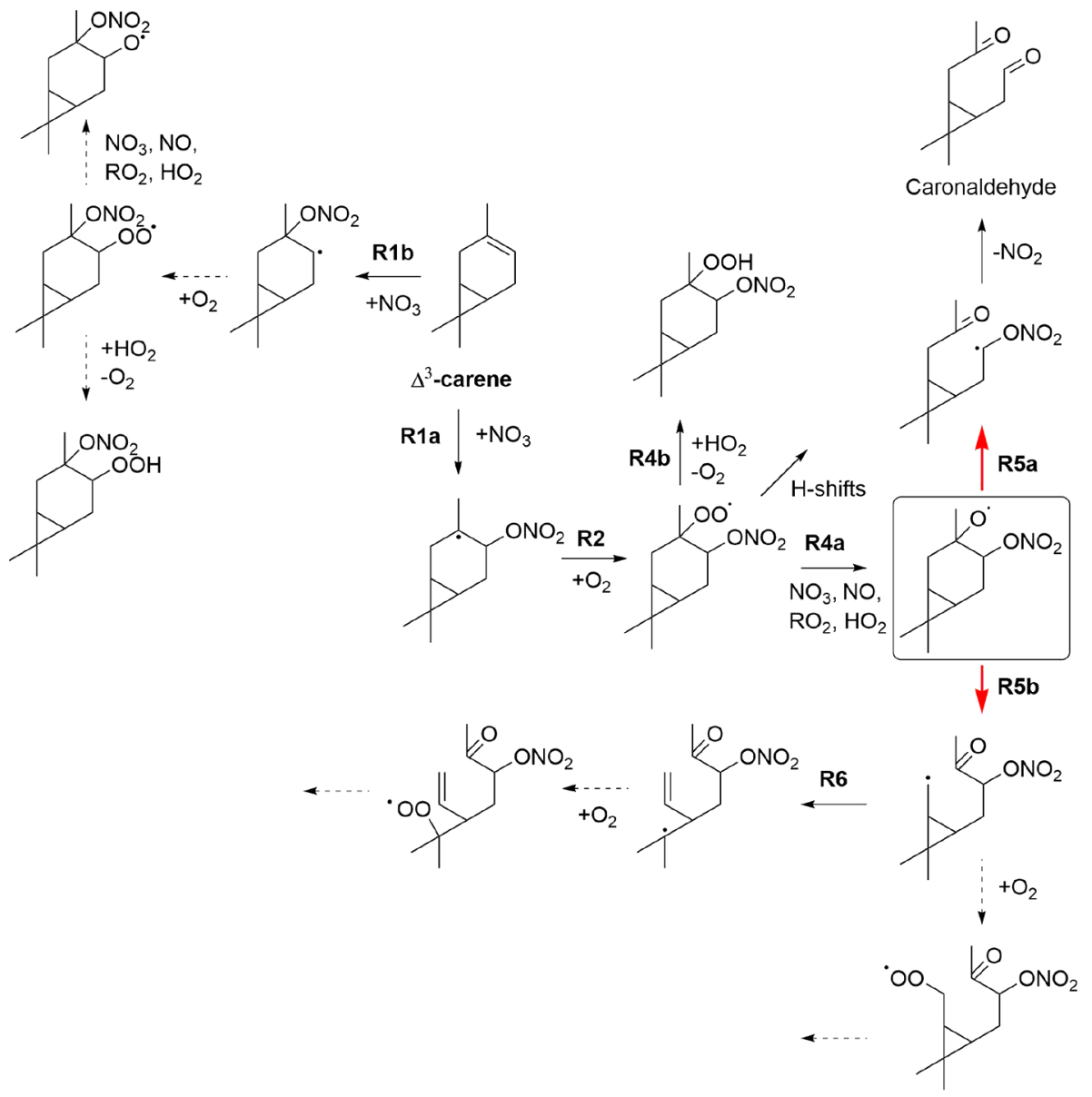

${ }^{a}$ Reactions studied here are labeled, while likely subsequent reactions not investigated in this study are indicated by dashed arrows. The reaction equivalent to $\mathbf{R} \mathbf{3}$ in Scheme 1 is not possible for $\Delta^{3}$-carene. The key $\beta$-nitrooxy-alkoxy radical is shown in the solid box with the bifurcating reactions highlighted with red arrows.

full details), to investigate the reason for the vast difference in SOA, nitrate, and carbonyl yields between the $\mathrm{NO}_{3}$-initiated oxidation of $\alpha$-pinene and $\Delta^{3}$-carene (the "+" enantiomers). We test the hypotheses arising from these computations with experimental data on the $\alpha$-pinene $+\mathrm{NO}_{3}$ reaction under simulated atmospheric conditions.

The reaction pathways for $\alpha$-pinene $+\mathrm{NO}_{3}$ and $\Delta^{3}$-carene + $\mathrm{NO}_{3}$ are illustrated in Schemes 1 and 2, respectively. The most likely first step of both reactions is the addition of nitrate to the double bond to form a nitrooxy-alkyl radical, with the major addition pathway forming the tertiary alkyl radical with a greater degree of substitution (reaction R1a in Schemes 1 and 2 ). The branching ratios for the two addition pathways in the $\alpha$-pinene $+\mathrm{NO}_{3}$ system have been recommended to be 0.65 and $0.35 . .^{32,33}$ See section S2 in the SI for thermodynamics of the addition reactions, and section S3 for a discussion of key reactions along the minor addition pathway $(\mathbf{R} \mathbf{1 b})$.

Under atmospheric conditions, alkyl radicals will usually undergo $\mathrm{O}_{2}$ addition reactions (reaction $\mathbf{R} 2$ in Schemes 1 and 2 ), to form peroxy radicals, at pseudounimolecular rates on the order of $10^{7} \mathrm{~s}^{-1}$. ${ }^{34}$ Each nitrooxy-peroxy radical has four isomers, as illustrated in Figure 1 for $\alpha$-pinene, and in Figure S1 for $\Delta^{3}$-carene. For both monoterpenes, the most thermodynamically favorable $\mathrm{NO}_{3}$ and $\mathrm{O}_{2}$ addition channels are those forming the $\mathrm{S}, \mathrm{S}$ isomer.
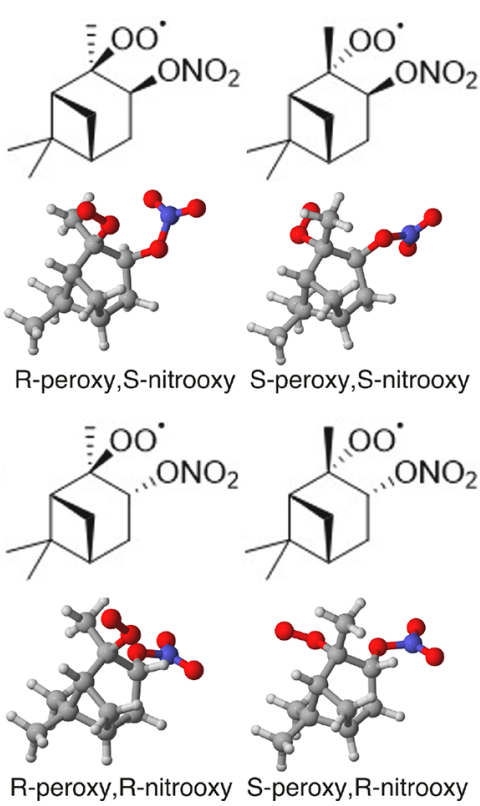

Figure 1. Structures of the four different isomers of the nitrooxyperoxy radical formed in the oxidation of $\alpha$-pinene by $\mathrm{NO}_{3}$, assuming initial radical addition to the secondary carbon atom. Color coding: gray $=\mathrm{C}$, white $=\mathrm{H}$, red $=\mathrm{O}$, blue $=\mathrm{N}$. 
Table 1. Barriers (Zero-Point Corrected Transition State - Reactant Electronic Energy Differences) and Multi-Conformer Transition State Theory (MC-TST) Reaction Rate Coefficients (298.15 K) Computed at the $\omega$ B97X-D/aug-cc-pVTZ Level for the Bond Scission Reactions R5a and R5b of the Nitrooxy-Alkoxy Radicals Formed in the $\alpha$-Pinene $+\mathrm{NO}_{3}$ and $\Delta^{3}$-Carene + $\mathrm{NO}_{3}$ Systems ${ }^{a}$

\begin{tabular}{|c|c|c|c|c|}
\hline alkoxy radical isomer & barrier for $\mathbf{R S a}^{b}(\mathrm{kcal} / \mathrm{mol})$ & rate coefficient for R5a $\left(\mathrm{s}^{-1}\right)$ & barrier for $\mathbf{R} \mathbf{5} \mathbf{b}^{c}(\mathrm{kcal} / \mathrm{mol})$ & rate coefficient for $\mathbf{R} \mathbf{5 b}\left(\mathrm{s}^{-1}\right)$ \\
\hline$\alpha$-pinene, R-alkoxy, S-nitrooxy & 4.8 & $1.5 \times 10^{9}$ & 9.4 & $3.6 \times 10^{6}$ \\
\hline$\alpha$-pinene, S-alkoxy, S-nitrooxy & 8.6 & $2.2 \times 10^{6}$ & 10.5 & $1.0 \times 10^{5}$ \\
\hline$\alpha$-pinene, R-alkoxy, R-nitrooxy & 6.1 & $1.7 \times 10^{8}$ & 10.6 & $1.3 \times 10^{5}$ \\
\hline$\alpha$-pinene, S-alkoxy, R-nitrooxy & 6.7 & $7.3 \times 10^{7}$ & 10.4 & $3.7 \times 10^{5}$ \\
\hline$\Delta^{3}$-carene, R-alkoxy, S-nitrooxy & 9.2 & $1.7 \times 10^{6}$ & 8.3 & $8.4 \times 10^{6}$ \\
\hline$\Delta^{3}$-carene, S-alkoxy, S-nitrooxy & 8.6 & $2.6 \times 10^{6}$ & 8.1 & $9.0 \times 10^{6}$ \\
\hline$\Delta^{3}$-carene, R-alkoxy, R-nitrooxy & 8.4 & $8.2 \times 10^{6}$ & 7.4 & $2.7 \times 10^{7}$ \\
\hline$\Delta^{3}$-carene, S-alkoxy, R-nitrooxy & 8.4 & $3.3 \times 10^{6}$ & 8.4 & $6.2 \times 10^{6}$ \\
\hline
\end{tabular}

For the hydroxyl-alkyl radical formed by $\mathrm{OH}$ addition to $\alpha$ pinene at the secondary carbon, a ring-breaking bond scission pathway leading to a hydroxyl-alkenyl radical has also been proposed. $^{35,36}$ This bond scission has a barrier of about 12 $\mathrm{kcal} / \mathrm{mol}$, making its thermal rate uncompetitive with $\mathrm{O}_{2}$ addition, but excess energy from the $\mathrm{OH}$ addition (around $30 \mathrm{kcal} / \mathrm{mol}$ ) may facilitate the reaction. ${ }^{35}$ We have identified an analogous reaction in the $\alpha$-pinene $+\mathrm{NO}_{3}$ system (reaction R3 in Scheme 1). Due to the slightly higher barrier (around 14 $\mathrm{kcal} / \mathrm{mol}$ ), and the significantly lower exothermicity of the $\mathrm{NO}_{3}$ addition reaction (around $20 \mathrm{kcal} / \mathrm{mol}$ ), our modeling (SI, section S5) indicates that this reaction is not competitive with $\mathrm{O}_{2}$ addition. A corresponding channel does not exist for the $\Delta^{3}$ carene $+\mathrm{NO}_{3}$ adduct. Nitrooxy-alkyl radical bond scissions can thus not explain the differences in SOA, nitrate, or carbonyl yields following addition of $\mathrm{NO}_{3}$ to either $\alpha$-pinene or $\Delta^{3}$ carene.

We considered possible $\mathrm{H}$-shift reactions of the firstgeneration nitrooxy-peroxy radicals. The constraints imposed by the two rings in each system prevent the OO group from reaching most hydrogens, as can be seen from Figure 1. The remaining $\mathrm{H}$ atoms are all difficult to abstract due to steric strain in the transition states and/or high $\mathrm{C}-\mathrm{H}$ bond strengths. We investigated all accessible $\mathrm{H}$-shifts for each peroxy radical (see section S6 in the SI for details). All calculated H-shift rate coefficients were below $10^{-4} \mathrm{~s}^{-1}$ for both monoterpenes. As the computational method employed likely overestimates the $\mathrm{H}$ shift rates, ${ }^{37}$ the peroxy radicals thus almost certainly have lifetimes long enough to undergo bimolecular reactions, which occur on a time scale of between 0.01 and $100 \mathrm{~s}$ under most atmospheric conditions. ${ }^{38}$

In the atmosphere, the peroxy radicals produced at night from $\mathrm{NO}_{3}$ chemistry will typically react with $\mathrm{HO}_{2}$ or other $\mathrm{RO}_{2}$ radicals, ${ }^{39}$ and during daytime the reaction with $\mathrm{NO}$ will contribute significantly. Understanding the products of this nitrooxy-peroxy radical chemistry is important, as it will determine the subsequent pathways. Alkoxy radicals will be produced by reactions of $\mathrm{RO}_{2}$ with $\mathrm{NO}$ or other radicals (R4a), while hydroperoxides are typically major products of the reaction with $\mathrm{HO}_{2}(\mathbf{R} 4 \mathbf{b})$.

Due to the large radical concentrations in most laboratory investigations of the oxidation of hydrocarbons by $\mathrm{NO}_{3}$, the peroxy radicals typically react with $\mathrm{NO}_{3}$ or themselves, leading primarily to the production of alkoxy radicals. ${ }^{38}$ It is thus unclear to what extent these previous investigations are relevant for the atmosphere, where $\mathrm{HO}_{2}$ radicals play such an important role. An $\alpha$-pinene $+\mathrm{NO}_{3}$ experiment conducted as part of the FIXCIT chamber study ${ }^{40}$ and analyzed here for the first time (see section S11) provides evidence for large production of RO from the reaction of $\mathrm{HO}_{2}$ with the $\mathrm{RO}_{2}$ radicals produced via $\alpha$ pinene $+\mathrm{NO}_{3}$. We find that the hydroperoxy nitrate yield is only $\sim 30 \%$ - much lower than, for example, in the equivalent chemistry of isoprene. ${ }^{41}$ The carbon budget is balanced by formation of pinonaldehyde ( $\sim 70 \%)$, with essentially no SOA being observed (molar yield of less than $1 \%$ ). Together, these yields suggest that the majority of the atmospheric bimolecular chemistry following addition of the nitrate radical to $\alpha$-pinene leads to the formation of the nitrooxy-alkoxy radicals even under atmospherically relevant $\mathrm{HO}_{2}$ dominated conditions (R4a). To our knowledge, however, there is no equivalent $\mathrm{HO}_{2}$-dominated laboratory study for $\Delta^{3}$-carene $+\mathrm{NO}_{3}$.

By analogy with the $\mathrm{OH}$-initiated oxidation of $\alpha$-pinene, ${ }^{42}$ perhaps it is not too surprising that the reaction of the tertiary peroxy radicals with $\mathrm{HO}_{2}$ has such a large yield of alkoxy radicals (R4a). The computed Gibbs free energy (at $298.15 \mathrm{~K}$ and $1 \mathrm{~atm}$ reference pressure) for the $\mathrm{RO}_{2}+\mathrm{HO}_{2} \rightarrow \mathrm{RO}+\mathrm{OH}$ $+\mathrm{O}_{2}$ reaction (SI section S7) varies between $-1.4 \mathrm{kcal} / \mathrm{mol}$ and $-5.2 \mathrm{kcal} / \mathrm{mol}$ for the four $\mathrm{NO}_{3}-\mathrm{RO}_{2}$ isomers from the $\alpha$ pinene $+\mathrm{NO}_{3}$ reaction, and $-2.3 \mathrm{kcal} / \mathrm{mol}$ and $-6.4 \mathrm{kcal} / \mathrm{mol}$ for those from $\Delta^{3}$-carene $+\mathrm{NO}_{3}$. The alkoxy-forming pathway is thus thermodynamically favorable for all $\mathrm{RO}_{2}$ radicals studied here.

A recent review of organic peroxy radical chemistry noted that, while chain-terminating formation of hydroperoxides $(\mathrm{ROOH})$ is dominant for simple alkylperoxy radicals, greater substitution favors alkoxy-forming channels. ${ }^{38}$ Consistent with this suggestion, it would be expected that the hydroperoxide yield from the less substituted peroxy radical from R1b is higher than that from Rla. We note that the measured yield of hydroperoxy nitrate in the $\alpha$-pinene $+\mathrm{NO}_{3}$ system is very close to the estimate of the branching ratio ( $\mathbf{R} \mathbf{1} \mathbf{a}$ vs $\mathbf{R} \mathbf{1} \mathbf{b}$ ), suggesting that perhaps $\mathbf{R} \mathbf{1 b}$ is the route to most of the observed hydroperoxide.

The retention of the nitrate group and the high yields of SOA produced following formation of the alkoxy radical in $\Delta^{3}$ carene $+\mathrm{NO}_{3}$ system compared to $\alpha$-pinene results from differences in the alkoxy radical scissions. Alkoxy radicals located on ring systems are known to undergo rapid ringbreaking reactions ( $\mathrm{C}-\mathrm{C}$ bond scissions)..$^{23,35,36,43}$ Each alkoxy radical studied here has two possible bond scission pathways that lead to ring breaking. Breaking the bond to the nitrooxy carbon ( $\beta$-nitrooxy-alkoxy scission, R5a in Schemes 1 and 2) 
leads to the formation of keto aldehydes (pinonaldehyde for $\alpha$ pinene and caronaldehyde for $\Delta^{3}$-carene) and recycling of $\mathrm{NO}_{2}{ }^{44}$ The alternative scission ( $\mathbf{R} 5 \mathbf{b}$ ) leads to a keto-nitrooxyalkyl radical. A pathway similar to $\mathrm{R5a}$ but involving $\mathrm{O}_{2}$ addition and subsequent prompt $\mathrm{HO}_{2}$ loss exists in the $\mathrm{OH}$ oxidation system. ${ }^{35,36}$

The barriers and estimated rate coefficients for reactions R5a and $\mathbf{R} \mathbf{5} \mathbf{b}$ are given in Table 1, with the lowest-energy transition states for the thermodynamically most favorable isomers illustrated in Figure 2. See SI section S8 for other isomers,

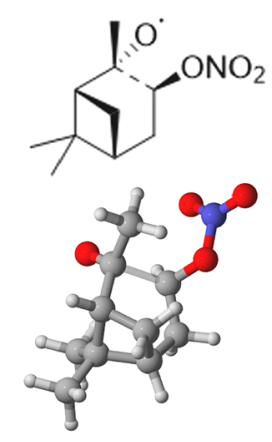

8.6

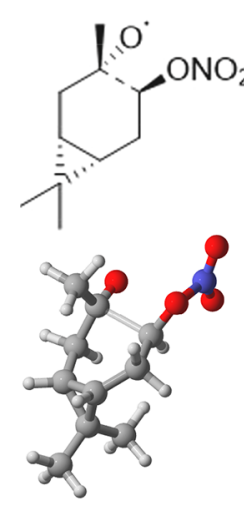

8.6

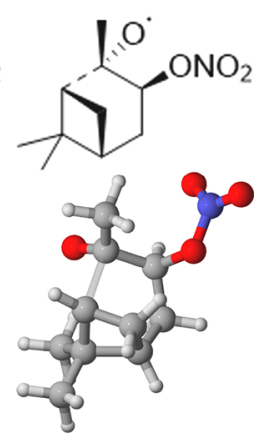

10.5

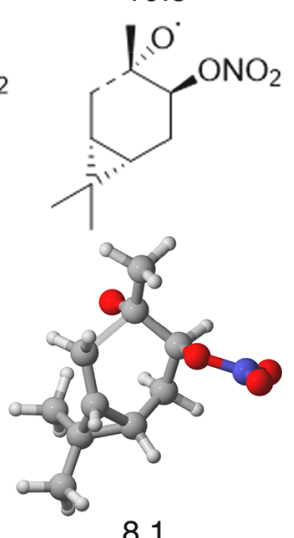

8.1
Figure 2. Transition states for the bond scission reactions of the S,S isomers of the nitrooxy-alkoxy radicals formed in the oxidation of $\alpha$ pinene (top) and $\Delta^{3}$-carene (bottom) by $\mathrm{NO}_{3}$, assuming initial radical addition to the secondary carbon atom. The reaction barriers (zeropoint corrected $\omega \mathrm{B} 97 \mathrm{X}-\mathrm{D} /$ aug-cc-pVTZ electronic energy differences between the lowest-energy transition states and reactants) in $\mathrm{kcal} / \mathrm{mol}$ are given under each structure. See Table 1 for details. Left column: transition states for reaction R5a. Right column: transition states for reaction $\mathbf{R} 5 \mathbf{b}$. Color coding as in Figure 1.

and section S9 for data on the $\alpha$-pinene $+\mathrm{OH}$ and $\Delta^{3}$-carene + $\mathrm{OH}$ systems. Alkoxy bond scission pathways typically compete with $\mathrm{H}$-shift reactions. ${ }^{45,46}$ For the nitrooxy-alkoxy radicals studied here, steric strain prevents most of these $\mathrm{H}$-shifts from occurring. However, in the S-alkoxy isomers, the hydrogens on one of the methyl groups attached to the $\mathrm{C}_{3} / \mathrm{C}_{4}$ ring are accessible. Alkoxy $\mathrm{H}$-shifts from primary hydrogen atoms typically have rate coefficients of around $10^{4}-10^{6} \mathrm{~s}^{-1}$ at room temperature, ${ }^{45,46}$ which suggests that these are not dominating. If these alkoxy $\mathrm{H}$-shifts are faster than suggested they could be competitive for the S,S isomer leading to additional minor products.

The $\alpha$-pinene $+\mathrm{NO}_{3}$ system shows a strong preference for $\mathrm{C}-\mathrm{C}\left(\mathrm{ONO}_{2}\right)$ scission ( $\left.\mathbf{R 5 a}\right)$, with differences in barrier heights between the two scission pathways varying between 1.9 and 4.6 $\mathrm{kcal} / \mathrm{mol}$, depending on the isomer, which corresponds to a difference of at least a factor of 20 in the reaction rates. By contrast, the relative barriers for the two pathways are within 1 $\mathrm{kcal} / \mathrm{mol}$ of each other for the $\Delta^{3}$-carene $+\mathrm{NO}_{3}$ system, with a slight preference for $\mathrm{C}-\mathrm{C}\left(\mathrm{H}_{2}\right)$ scission $(\mathbf{R 5 b})$. This leads to a significantly different product distribution for the two monoterpenes. Our prediction for $\alpha$-pinene $+\mathrm{NO}_{3}$ is in qualitative agreement with the structure-activity relationship (SAR) of Vereecken and Peeters, ${ }^{47}$ which also predicts a lower barrier for R5a compared to R5b. For $\Delta^{3}$-carene $+\mathrm{NO}_{3}$, naive application of the SAR would predict R5a to be faster than $\mathbf{R 5 b}$, but this is likely due to the treatment of the complex substituent on the $\beta$-carbon atom of the product alkyl radical $(\gamma$ to the original alkoxy carbon) as a simple alkyl group. For the $\mathrm{OH}$ oxidation systems (SI section S9) we find, as also predicted by the $\mathrm{SAR}^{47}$ a preference for $\mathrm{C}-\mathrm{C}(\mathrm{OH})$ scission in both $\alpha$ pinene and $\Delta^{3}$-carene systems; however, more pronounced in the $\alpha$-pinene $+\mathrm{OH}$ system. Our theoretical results on $\alpha$-pinene $+\mathrm{OH}$ agree with previous investigations. ${ }^{35,36}$

Because of the large difference between the bond scission rates, we find, consistent with laboratory data, that the nitrooxyalkoxy radicals formed in the $\alpha$-pinene $+\mathrm{NO}_{3}$ system will almost exclusively form pinonaldehyde. By contrast, both the formation pathways of caronaldehyde and the keto-nitrooxyalkyl radical are accessible in high yield in the $\Delta^{3}$-carene $+\mathrm{NO}_{3}$ system. The keto-nitrooxy-alkyl radical can undergo further reactions to form HOM that can partition to SOA.

Subtle differences in the stabilities of the radicals formed by the $\mathrm{C}-\mathrm{C}$ scission reactions determine the fate of the nitrooxy alkoxy radicals formed in the $\mathrm{NO}_{3}$-initiated oxidation of monoterpenes. In the $\alpha$-pinene case, the unfavorable formation of a radical center on the $\mathrm{C}_{4}$ ring $^{48-50}$ in reaction $\mathbf{R 5 b}$ drives the $\mathrm{NO}_{2}$ loss and pinonaldehyde formation ( $\left.25 \mathrm{a}\right)$. In the $\Delta^{3}$ carene case, our results indicate that both scission pathways are competitive, likely due to the added stabilization of the primary alkyl radical formed in reaction $\mathbf{R} \mathbf{5 b}$ by the cyclopropyl derived substituent. Of the other atmospherically relevant monoterpenes ${ }^{2}$ with cyclic structures, $\beta$-pinene and sabinene contain exocyclic double bonds, and their $\mathrm{NO}_{3}$ oxidation will likely lead predominantly to nitrooxy alkoxy radicals where the nitrooxy group is not located on the ring. Their scission reactions will thus lead almost exclusively to products retaining the nitrooxy group. ${ }^{47}$ Limonene contains both an endo- and an exocyclic double bond. $\mathrm{NO}_{3}$ attack on the former would lead to nitrooxy alkoxy radicals similar to those formed in the $\Delta^{3}$-carene $+\mathrm{NO}_{3}$ reaction. However, due to the lack of the extra stabilization of the primary alkyl radical formed in the analogue of reaction $\mathbf{R} 5 \mathbf{b}$, the branching ratio of the two bond scission pathways may be more weighted toward the $\mathrm{NO}_{2}$ loss pathway. In comparison, the observed organic nitrate molar yield for limonene was $30 \%{ }^{51}$ compared to $70 \%$ for $\Delta^{3}$-carene. ${ }^{28,29}$

Analogous bifurcation in $\beta$ nitrooxy-alkoxy radical scission occurs in the oxidation of the two major organonitrates produced in the oxidation of isoprene by $\mathrm{OH}$ in the presence of NO. In this system, experiments show that decomposition of the nitrooxy-alkoxy radical leads to minimal $\mathrm{NO}_{x}$ recycling for a secondary nitrooxy group. ${ }^{52}$ We present calculations (SI section S12) that show, however, that the $\mathrm{NO}_{x}$ recycling is likely much higher for the structurally similar tertiary nitrooxy-alkoxy radical. Again, this illustrates that the competition between $\beta$ scission of the nitrooxy-alkoxy radical and alternative fragmentation pathways that retain this bond is sensitive to subtle structural differences. 
As established previously for $\alpha$-pinene $+\mathrm{OH}^{23,35,36}$ we predict that the hydroxy alkoxy radicals formed in the $\alpha$-pinene $+\mathrm{OH}$ and $\Delta^{3}$-carene $+\mathrm{OH}$ systems will almost exclusively form pinonaldehyde and caronaldehyde, respectively (SI section S9). The reported SOA formation in these systems therefore likely involves either further $\mathrm{OH}$ reactions of the aldehydes with oxidation products undergoing for example oligomerization, or competing reaction steps earlier in the oxidation mechanism, such as alkyl radical bond scission, or $\mathrm{H}$ abstraction by $\mathrm{OH}$ rather than addition. ${ }^{53}$ Since alkyl radical bond scission is not available to the $\Delta^{3}$-carene $+\mathrm{OH}$ system, it could therefore be expected to have a smaller SOA yield than $\alpha$ pinene $+\mathrm{OH}$. This is consistent with the generally higher SOA yields reported for $\alpha$-pinene $+\mathrm{OH}$ (e.g., $24-28 \%$ for $60-70 \mu \mathrm{g}$ $\mathrm{m}^{-3}$ of total OA) $)^{54}$ compared to those for $\Delta^{3}$-carene $+\mathrm{OH}$ (e.g., $14-16 \%$ for $55-65 \mu \mathrm{g} \mathrm{m}^{-3}$ of total OA). ${ }^{55}$

The observed ${ }^{28}$ high SOA and nitrate yields, and low keto aldehyde (caronaldehyde) yields, from $\mathrm{NO}_{3}$-initiated $\Delta^{3}$-carene oxidation are likely explained by further reactions of the ketonitrooxy-alkyl radical formed by reaction $\mathbf{R} \mathbf{5 b}$. This radical may add $\mathrm{O}_{2}$ either directly, or after a second ring-breaking reaction forming a more highly substituted alkyl radical (reaction R6 in Scheme 2). We find a barrier of around $6 \mathrm{kcal} / \mathrm{mol}$ for R6 (SI, section S10), implying that $\mathbf{R} 6$ and direct $\mathrm{O}_{2}$ addition may both be competitive. Due to their greater flexibility, both ketonitrooxy-peroxy radicals may undergo $\mathrm{H}$-shifts much faster than the first-generation nitrooxy-peroxy radicals. Alternatively, bimolecular reactions could form reactive keto-nitrooxy-alkoxy radicals - in both cases ultimately leading to more oxidized and less volatile organonitrate products.

Our results illustrate how minor structural differences between monoterpenes can lead to very different reaction mechanisms, product distributions, and atmospheric impacts. Extrapolating or generalizing measurement results from a single terpene to all monoterpenes can thus lead to serious errors in predicted SOA and organonitrate yields in model simulations, especially if the terpene used is $\alpha$-pinene, as its reaction mechanism is likely unique among the monoterpenes.

\section{METHODS}

Computational. To calculate reaction rates, we applied a modified version our recently published approach using both multiconformer transition state theory (MC-TST) and the lowest energy conformer TST (LC-TST) methods. ${ }^{37}$ This involves an initial systematic conformational search using the

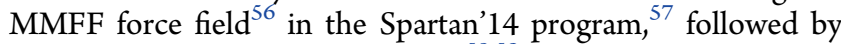
B3LYP $/ 6-31+\mathrm{G}(\mathrm{d})$ optimizations, ${ }^{58,59}$ and finally $\omega$ B97X-D/ aug-cc-pVTZ ${ }^{60-62}$ optimizations using Gaussian $09^{63}$ and adding Eckart tunneling ${ }^{64}$ corrections. We investigated all conformers and calculated LC-TST rates for most reactions, while for the central reactions (R5a and R5b in Schemes 1 and 2) we calculated MC-TST rates. ROHF-ROCCSD(T)-F12a/ VDZ-F12 single-point calculations ${ }^{65}$ on reaction $\mathbf{R} 3$ were performed using Molpro 2012.1. ${ }^{66}$ Reaction dynamic modeling for $\mathbf{R} 3$ was performed using the MESMER program (see SI section S5). ${ }^{67}$ Details on the computational approach are given in SI section $\mathrm{S} 1$.

Experimental. In the FIXCIT chamber experiment, ${ }^{40} \alpha$ pinene was added to a darkened $24 \mathrm{~m}^{3}$ chamber containing $\mathrm{NO}_{2}, \mathrm{O}_{3}$ (and consequently $\mathrm{NO}_{3}$ and $\mathrm{N}_{2} \mathrm{O}_{5}$ ), and $\mathrm{H}_{2} \mathrm{CO}$ (and consequently $\mathrm{HO}_{2}$ ). The chamber was first filled with $\mathrm{NO}_{3}$ and $\mathrm{HO}_{2}$ radicals produced via addition of $\sim 75 \mathrm{ppb} \mathrm{O}_{3}, \sim 150 \mathrm{ppb}$ $\mathrm{NO}_{2}$, and $\sim 8 \mathrm{ppm}$ formaldehyde, into which a volume of $\alpha$ - pinene was gradually injected equivalent to $\sim 35 \mathrm{ppb}$. The consumption of $\alpha$-pinene and production of pinonaldehyde was monitored by a switchable reagent ion high-resolution time-offlight mass spectrometer (SRI-ToF-MS) using $\mathrm{H}_{3} \mathrm{O}^{+}$reagent. The hydroperoxynitrate production was monitored by a timeof-flight chemical ionization mass spectrometer (ToF-CIMS) using $\mathrm{CF}_{3} \mathrm{O}^{-}$reagent, and the organic aerosol production was monitored by an aerosol mass spectrometer (AMS). After $3 \mathrm{~h}$ of reaction, $\sim 20 \mathrm{ppb}$ of $\alpha$-pinene had been depleted and $\sim 4$ $\mathrm{ppb}$ of hydroperoxynitrate formed. The branching ratio for the $\mathrm{NO}_{3}-\mathrm{RO}_{2}+\mathrm{HO}_{2} \rightarrow \mathrm{NO}_{3}-\mathrm{ROOH}+\mathrm{O}_{2}$ channel was $30 \%$ (15$45 \%)$, which includes a correction for the fraction of $\alpha$-pinene reaction that reacted with $\mathrm{O}_{3}$ (see SI section S11 for more experimental details and description of uncertainties). Approximately $17 \mathrm{ppb}$ of pinonaldehyde is produced during the same period. Minimal SOA production is observed $\left(\sim 1.5 \mu \mathrm{g} \mathrm{m}^{-3}\right.$ organic aerosol, unseeded).

\section{ASSOCIATED CONTENT}

\section{Supporting Information}

The Supporting Information is available free of charge on the ACS Publications website at DOI: 10.1021/acs.jpclett.7b01038.

Full computational details; thermodynamics of the initial radical and $\mathrm{O}_{2}$ addition reactions; data on selected further reactions along the minor $\mathrm{NO}_{3}$ addition pathway to $\alpha$-pinene; pictures of $\Delta^{3}$-carene $+\mathrm{NO}_{3}$ nitrooxyperoxy radical isomers; reaction kinetic modeling of the alkyl radical bond scission reaction in the $\alpha$-pinene $-\mathrm{NO}_{3}$ adduct; $\mathrm{H}$-shift rates for nitrooxy-peroxy radicals formed in the nitrate oxidation of $\alpha$-pinene and $\Delta^{3}$-carene; thermodynamics of nitrooxy-alkoxy formation from reaction of nitrooxy-peroxy radicals with $\mathrm{HO}_{2}$; pictures of transition states for all isomers for the alkoxy radical bond scission reactions in the $\alpha$-pinene $+\mathrm{NO}_{3}$ and $\Delta^{3}$ carene $+\mathrm{NO}_{3}$ systems; data on alkoxy radical bond scission reactions in the $\alpha$-pinene $+\mathrm{OH}$ and $\Delta^{3}$-carene + $\mathrm{OH}$ systems; transition states and energetics for reaction R6 (bond scission in the keto-nitrooxy-alkyl radical formed in the $\Delta^{3}$-carene $+\mathrm{NO}_{3}$ system by reaction R5b); detailed description of experimental instrumentation; alkoxy bond breaking reactions in isoprene-derived nitrooxy-alkoxy radicals. (PDF)

Gaussian.log files and Molpro.out files (ZIP)

\section{AUTHOR INFORMATION}

\section{Corresponding Authors}

*E-mail: theo.kurten@helsinki.fi, Tel: +358 505260123 (T.K.)

*E-mail: hgk@chem.ku.dk, Tel +45 35320334 (H.G.K.)

ORCID $\odot$

Theo Kurtén: 0000-0002-6416-4931

Kristian H. Møller: 0000-0001-8070-8516

Paul O. Wennberg: 0000-0002-6126-3854

Henrik G. Kjaergaard: 0000-0002-7275-8297

Present Address

National Center for Atmospheric Research, Boulder, Colorado 80301, USA

\section{Notes}

The authors declare no competing financial interest. 


\section{ACKNOWLEDGMENTS}

From the FIXCIT campaign, we thank Matthew Coggon and John Seinfeld for AMS data, Jeong-Hoo Park, Allen Goldstein, John Mak, and Alex Guenther for the PTR-MS data, John Crounse, Alex Teng and Kelvin Bates for the ToF-CIMS data and their work organizing and conducting the experiment. We also thank Alan Shusterman, Catherine Neshyba, Katie Stellmach, Rasmus V. Otkjær, Noora Hyttinen, Camilla Mia Tram, and Benjamin N. Frandsen for helpful discussions. T.K. thanks the Academy of Finland (266388) for funding and the CSC IT Center for Science in Espoo, Finland, for computing time. H.G.K. and K.H.M. thank the Center for Exploitation of Solar Energy, University of Copenhagen and the Danish Center for Scientific Computing for funding. POW thanks the NSF for funding (Grant No. CHE-1508526 and AGS-1240604). J.L.F. gratefully acknowledges sabbatical support from the U.S. Fulbright Scholar Program and research funding from the NOAA Climate Program Office's AC4 program (Grant No. NA13OAR4310070). The National Center for Atmospheric Research is sponsored by the National Science Foundation.

\section{REFERENCES}

(1) Jimenez, J. L.; Canagaratna, M. R.; Donahue, N. M.; Prevot, A. S. H.; Zhang, Q.; Kroll, J. H.; DeCarlo, P. F.; Allan, J. D.; Coe, H.; Ng, N. L.; Aiken, A. C.; Docherty, K. S.; Ulbrich, I. M.; Grieshop, A. P.; Robinson, A. L.; Duplissy, J.; Smith, J. D.; Wilson, K. R.; Lanz, V. A.; Hueglin, C.; Sun, Y. L.; Tian, J.; Laaksonen, A.; Raatikainen, T.; Rautiainen, J.; Vaattovaara, P.; Ehn, M.; Kulmala, M.; Tomlinson, J. M.; Collins, D. R.; Cubison, M. J.; Dunlea, J.; Huffman, J. A.; Onasch, T. B.; Alfarra, M. R.; Williams, P. I.; Bower, K.; Kondo, Y.; Schneider, J.; Drewnick, F.; Borrmann, S.; Weimer, S.; Demerjian, K.; Salcedo, D.; Cottrell, L.; Griffin, R.; Takami, A.; Miyoshi, T.; Hatakeyama, S.; Shimono, A.; Sun, J. Y.; Zhang, Y. M.; Dzepina, K.; Kimmel, J. R.; Sueper, D.; Jayne, J. T.; Herndon, S. C.; Trimborn, A. M.; Williams, L. R.; Wood, E. C.; Middlebrook, A. M.; Kolb, C. E.; Baltensperger, U.; Worsnop, D. R. Evolution of Organic Aerosols in the Atmosphere. Science 2009, 326, 1525-1529.

(2) Sindelarova, K.; Granier, C.; Bouarar, I.; Guenther, A.; Tilmes, S.; Stavrakou, T.; Müller, J. F.; Kuhn, U.; Stefani, P.; Knorr, W. Global Data Set of Biogenic VOC Emissions Calculated by the MEGAN Model Over the Last 30 Years. Atmos. Chem. Phys. 2014, 14, 93179341.

(3) IPCC 2013: Climate Change 2013: The Physical Science Basis. Contribution of Working Group I to the Fifth Assessment Report of the Intergovernmental Panel on Climate Change Stocker, T. F., Qin, D., Plattne, G.-K., Tignor, M. M. B., Allen, S. K., Boschung, J., Nauels, A., Xia, Y., Bex, V., Midgley, P. M., Eds.; Cambridge University Press: Cambridge/New York, 2013; 1535 pp.

(4) Brauer, M.; Freedman, G.; Frostad, J.; van Donkelaar, A.; Martin, R. V.; Dentener, F.; Dingenen, R. v.; Estep, K.; Amini, H.; Apte, J. S.; Balakrishnan, K.; Barregard, L.; Broday, D.; Feigin, V.; Ghosh, S.; Hopke, P. K.; Knibbs, L. D.; Kokubo, Y.; Liu, Y.; Ma, S.; Morawska, L.; Sangrador, J. L. T.; Shaddick, G.; Anderson, H. R.; Vos, T.; Forouzanfar, M. H.; Burnett, R. T.; Cohen, A. Ambient Air Pollution Exposure Estimation for the Global Burden of Disease 2013. Environ. Sci. Technol. 2016, 50, 79-88.

(5) Slowik, J. G.; Stroud, C.; Bottenheim, J. W.; Brickell, P. C.; Chang, R. Y. W.; Liggio, J.; Makar, P. A.; Martin, R. V.; Moran, M. D.; Shantz, N. C.; Sjostedt, S. J.; van Donkelaar, A.; Vlasenko, A.; Wiebe, H. A.; Xia, A. G.; Zhang, J.; Leaitch, W. R.; Abbatt, J. P. D. Characterization of a Large Biogenic Secondary Organic Aerosol Event from Eastern Canadian Forests. Atmos. Chem. Phys. 2010, 10, 28252845.

(6) Paulot, F.; Henze, D. K.; Wennberg, P. O. Impact of the Isoprene Photochemical Cascade on Tropical Ozone. Atmos. Chem. Phys. 2012, $12,1307-1325$.
(7) Hoyle, C. R.; Berntsen, T.; Myhre, G.; Isaksen, I. S. A. Secondary Organic Aerosol in the Global Aerosol - Chemical Transport Model Oslo CTM2. Atmos. Chem. Phys. 2007, 7, 5675-5694.

(8) Pye, H. O. T.; Chan, A. W. H.; Barkley, M. P.; Seinfeld, J. H. Global Modeling of Organic Aerosol: The Importance of Reactive Nitrogen (NOx and NO3). Atmos. Chem. Phys. 2010, 10, 1126111276.

(9) Pye, H. O. T.; Luecken, D. J.; Xu, L.; Boyd, C. M.; Ng, N. L.; Baker, K. R.; Ayres, B. R.; Bash, J. O.; Baumann, K.; Carter, W. P. L.; Edgerton, E.; Fry, J. L.; Hutzell, W. T.; Schwede, D. B.; Shepson, P. B. Modeling the Current and Future Roles of Particulate Organic Nitrates in the Southeastern United States. Environ. Sci. Technol. 2015, 49, 14195-14203.

(10) Ng, N. L.; Brown, S. S.; Archibald, A. T.; Atlas, E.; Cohen, R. C.; Crowley, J. N.; Day, D. A.; Donahue, N. M.; Fry, J. L.; Fuchs, H.; Griffin, R. J.; Guzman, M. I.; Herrmann, H.; Hodzic, A.; Iinuma, Y.; Jimenez, J. L.; Kiendler-Scharr, A.; Lee, B. H.; Luecken, D. J.; Mao, J.; McLaren, R.; Mutzel, A.; Osthoff, H. D.; Ouyang, B.; Picquet-Varrault, B.; Platt, U.; Pye, H. O. T.; Rudich, Y.; Schwantes, R. H.; Shiraiwa, M.; Stutz, J.; Thornton, J. A.; Tilgner, A.; Williams, B. J.; Zaveri, R. A. Nitrate Radicals and Biogenic Volatile Organic Compounds: Oxidation, Mechanisms, and Organic Aerosol. Atmos. Chem. Phys. 2017, 17, 2103-2162.

(11) Geyer, A.; Alicke, B.; Ackermann, R.; Martinez, M.; Harder, H.; Brune, W.; di Carlo, P.; Williams, E.; Jobson, T.; Hall, S.; Shetter, R.; Stutz, J. Direct Observations of Daytime NO3: Implications for Urban Boundary Layer Chemistry. J. Geophys. Res. 2003, 108, 4368.

(12) Ayres, B. R.; Allen, H. M.; Draper, D. C.; Brown, S. S.; Wild, R. J.; Jimenez, J. L.; Day, D. A.; Campuzano-Jost, P.; Hu, W.; de Gouw, J.; Koss, A.; Cohen, R. C.; Duffey, K. C.; Romer, P.; Baumann, K.; Edgerton, E.; Takahama, S.; Thornton, J. A.; Lee, B. H.; LopezHilfiker, F. D.; Mohr, C.; Wennberg, P. O.; Nguyen, T. B.; Teng, A.; Goldstein, A. H.; Olson, K.; Fry, J. L. Organic Nitrate Aerosol Formation via NO3 + Biogenic Volatile Organic Compounds in the Southeastern United States. Atmos. Chem. Phys. 2015, 15, 1337713392.

(13) Rollins, A. W.; Browne, E. C.; Min, K. E.; Pusede, S. E.; Wooldridge, P. J.; Gentner, D. R.; Goldstein, A. H.; Liu, S.; Day, D. A.; Russell, L. M.; Cohen, R. C. Evidence for NOx Control over Nighttime SOA Formation. Science 2012, 337, 1210-1212.

(14) Fry, J. L.; Draper, D. C.; Zarzana, K. J.; Campuzano-Jost, P.; Day, D. A.; Jimenez, J. L.; Brown, S. S.; Cohen, R. C.; Kaser, L.; Hansel, A.; Cappellin, L.; Karl, T.; Hodzic Roux, A.; Turnipseed, A.; Cantrell, C.; Lefer, B. L.; Grossberg, N. Observations of Gas- and Aerosol-Phase Organic Nitrates at BEACHON-RoMBAS 2011. Atmos. Chem. Phys. 2013, 13, 8585-8605.

(15) Xu, L.; Suresh, S.; Guo, H.; Weber, R. J.; Ng, N. L. Aerosol Characterization over the Southeastern United States using HighResolution Aerosol Mass Spectrometry: Spatial and Seasonal Variation of Aerosol Composition and Sources with a Focus on Organic Nitrates. Atmos. Chem. Phys. 2015, 15, 7307-7336.

(16) Kiendler-Scharr, A.; Mensah, A. A.; Friese, E.; Topping, D.; Nemitz, E.; Prevot, A. S. H.; Äijälä, M.; Allan, J.; Canonaco, F.; Canagaratna, M.; Carbone, S.; Crippa, M.; Dall Osto, M.; Day, D. A.; De Carlo, P.; Di Marco, C. F.; Elbern, H.; Eriksson, A.; Freney, E.; Hao, L.; Herrmann, H.; Hildebrandt, L.; Hillamo, R.; Jimenez, J. L.; Laaksonen, A.; McFiggans, G.; Mohr, C.; O’Dowd, C.; Otjes, R.; Ovadnevaite, J.; Pandis, S. N.; Poulain, L.; Schlag, P.; Sellegri, K.; Swietlicki, E.; Tiitta, P.; Vermeulen, A.; Wahner, A.; Worsnop, D.; Wu, H. C. Ubiquity of Organic Nitrates from Nighttime Chemistry in the European Submicron Aerosol. Geophys. Res. Lett. 2016, 43, 77357744.

(17) Horowitz, L. W.; Fiore, A. M.; Milly, G. P.; Cohen, R. C.; Perring, A.; Wooldridge, P. J.; Hess, P. G.; Emmons, L. K.; Lamarque, J.-F. Observational Constraints on the Chemistry of Isoprene Nitrates over the Eastern United States. J. Geophys. Res. 2007, 112, D12S08.

(18) Pierce, J. R.; Riipinen, I.; Kulmala, M.; Ehn, M.; Petäjä, T.; Junninen, H.; Worsnop, D. R.; Donahue, N. M. Quantification of the 
Volatility of Secondary Organic Compounds in Ultrafine Particles During Nucleation Events. Atmos. Chem. Phys. 2011, 11, 9019-9036. (19) Hallquist, M.; Wenger, J. C.; Baltensperger, U.; Rudich, Y.; Simpson, D.; Claeys, M.; Dommen, J.; Donahue, N. M.; George, C.; Goldstein, A. H.; Hamilton, J. F.; Herrmann, H.; Hoffmann, T.; Iinuma, Y.; Jang, M.; Jenkin, M. E.; Jimenez, J. L.; Kiendler-Scharr, A.; Maenhaut, W.; McFiggans, G.; Mentel, T. F.; Monod, A.; Prévôt, A. S. H.; Seinfeld, J. H.; Surratt, J. D.; Szmigielski, R.; Wildt, J. The Formation, Properties and Impact of Secondary Organic Aerosol: Current and Emerging Issues. Atmos. Chem. Phys. 2009, 9, 5155-5236.

(20) Crounse, J. D.; Nielsen, L. B.; Jørgensen, S.; Kjaergaard, H. G.; Wennberg, P. O. Autoxidation of Organic Compounds in the Atmosphere. J. Phys. Chem. Lett. 2013, 4, 3513-3520.

(21) Ehn, M.; Thornton, J. A.; Kleist, E.; Sipilä, M.; Junninen, H.; Pullinen, I.; Springer, M.; Rubach, F.; Tillmann, R.; Lee, B.; LopezHilfiker, F.; Andres, S.; Acir, I.-H.; Rissanen, M.; Jokinen, T.; Schobesberger, S.; Kangasluoma, J.; Kontkanen, J.; Nieminen, T.; Kurtén, T.; Nielsen, L. B.; Jørgensen, S.; Kjaergaard, H. G.; Canagaratna, M.; Maso, M. D.; Berndt, T.; Petäjä, T.; Wahner, A.; Kerminen, V.-M.; Kulmala, M.; Worsnop, D. R.; Wildt, J.; Mentel, T. F. A Large Source of Low-Volatility Secondary Organic Aerosol. Nature 2014, 506, 476-479.

(22) Rissanen, M. P.; Kurtén, T.; Sipilä, M.; Thornton, J. A.; Kangasluoma, J.; Sarnela, N.; Junninen, H.; Jørgensen, S.; Schallhart, S.; Kajos, M. K.; Taipale, R.; Springer, M.; Mentel, T. F.; Ruuskanen, T.; Petäjä, T.; Worsnop, D. R.; Kjaergaard, H. G.; Ehn, M. The Formation of Highly Oxidized Multifunctional Products in the Ozonolysis of Cyclohexene. J. Am. Chem. Soc. 2014, 136, 1559615606.

(23) Vereecken, L.; Müller, J. F.; Peeters, J. Low-Volatility PolyOxygenates in the OH-Initiated Atmospheric Oxidation of $\alpha$-Pinene: Impact of Non-Traditional Peroxyl Radical Chemistry. Phys. Chem. Chem. Phys. 2007, 9, 5241-5248.

(24) Peeters, J.; Nguyen, T. L.; Vereecken, L. HOx Radical Regeneration in the Oxidation of Isoprene. Phys. Chem. Chem. Phys. 2009, 11, 5935-5939.

(25) Savee, J. D.; Papajak, E.; Rotavera, B.; Huang, H.; Eskola, A. J.; Welz, O.; Sheps, L.; Taatjes, C. A.; Zador, J.; Osborn, D. L. Direct Observation and Kinetics of a Hydroperoxyalkyl Radical (QOOH). Science 2015, 347, 643-646.

(26) Griffin, R. J.; Cocker, D. R.; Seinfeld, J. H.; Dabdub, D. Estimate of Global Atmospheric Organic Aerosol from Oxidation of Biogenic Hydrocarbons. Geophys. Res. Lett. 1999, 26, 2721-2724.

(27) Jokinen, T.; Berndt, T.; Makkonen, R.; Kerminen, V.-M.; Junninen, H.; Paasonen, P.; Stratmann, F.; Herrmann, H.; Guenther, A. B.; Worsnop, D. R.; Kulmala, M.; Ehn, M.; Sipilä, M. Production of Extremely Low Volatile Organic Compounds from Biogenic Emissions: Measured Yields and Atmospheric Implications. Proc. Natl. Acad. Sci. U. S. A. 2015, 112, 7123-7128.

(28) Fry, J. L.; Draper, D. C.; Barsanti, K. C.; Smith, J. N.; Ortega, J.; Winkler, P. M.; Lawler, M. J.; Brown, S. S.; Edwards, P. M.; Cohen, R. C.; Lee, L. Secondary Organic Aerosol Formation and Organic Nitrate Yield from NO3 Oxidation of Biogenic Hydrocarbons. Environ. Sci. Technol. 2014, 48, 11944-11953.

(29) Hallquist, M.; Wängberg, I.; Ljungström, E.; Barnes, I.; Becker, K.-H. Aerosol and Product Yields from NO3 Radical-Initiated Oxidation of Selected Monoterpenes. Environ. Sci. Technol. 1999, 33, 553-559.

(30) Spittler, M.; Barnes, I.; Bejan, I.; Brockmann, K. J.; Benter, T.; Wirtz, K. Reactions of NO3 Radicals with Limonene and $\alpha$-Pinene: Product and SOA Formation. Atmos. Environ. 2006, 40, S116-S127.

(31) Moldanova, J.; Ljungström, E. Modelling of Particle Formation from NO3 Oxidation of Selected Monoterpenes. J. Aerosol Sci. 2000, 31, 1317-1333.

(32) Jenkin, M. E.; Saunders, S. M.; Pilling, M. J. The Tropospheric Degradation of Volatile Organic Compounds: A Protocol for Mechanism Development. Atmos. Environ. 1997, 31, 81-104.

(33) Saunders, S. M.; Jenkin, M. E.; Derwent, R. G.; Pilling, M. J. Protocol for the Development of the Master Chemical Mechanism,
MCM v3 (Part A): Tropospheric Degradation of Non-Aromatic Volatile Organic Compounds. Atmos. Chem. Phys. 2003, 3, 161-180.

(34) Park, J.; Jongsma, C. G.; Zhang, R.; North, S. W. OH/OD Initiated Oxidation of Isoprene in the Presence of $\mathrm{O} 2$ and NO. J. Phys. Chem. A 2004, 108, 10688-10697.

(35) Vereecken, L.; Peeters, J. Theoretical Study of the Formation of Acetone in the $\mathrm{OH}$-Initiated Atmospheric Oxidation of $\alpha$-Pinene. J. Phys. Chem. A 2000, 104, 11140-11146.

(36) Dibble, T. S. Reactions of the Alkoxy Radicals Formed Following OH-Addition to $\alpha$-Pinene and $\beta$-Pinene. $\mathrm{C}-\mathrm{C}$ Bond Scission Reactions. J. Am. Chem. Soc. 2001, 123, 4228-4234.

(37) Møller, K. H.; Otkjær, R. V.; Hyttinen, N.; Kurtén, T.; Kjaergaard, H. G. Cost-Effective Implementation of Multiconformer Transition State Theory for Peroxy Radical Hydrogen Shift Reactions. J. Phys. Chem. A 2016, 120, 10072-10087.

(38) Orlando, J. J.; Tyndall, G. S. Laboratory Studies of Organic Peroxy Radical Chemistry: An Overview with Emphasis on Recent Issues of Atmospheric Significance. Chem. Soc. Rev. 2012, 41, 62946317.

(39) Xie, Y.; Paulot, F.; Carter, W. P. L.; Nolte, C. G.; Luecken, D. J.; Hutzell, W. T.; Wennberg, P. O.; Cohen, R. C.; Pinder, R. W. Understanding the Impact of Recent Advances in Isoprene Photooxidation on Simulations of Regional Air Quality. Atmos. Chem. Phys. 2013, 13, 8439-8455.

(40) Nguyen, T. B.; Crounse, J. D.; Schwantes, R. H.; Teng, A. P.; Bates, K. H.; Zhang, X.; St. Clair, J. M.; Brune, W. H.; Tyndall, G. S.; Keutsch, F. N.; Seinfeld, J. H.; Wennberg, P. O. Overview of the Focused Isoprene eXperiment at the California Institute of Technology (FIXCIT): Mechanistic Chamber Studies on the Oxidation of Biogenic Compounds. Atmos. Chem. Phys. 2014, 14, 13531-13549.

(41) Schwantes, R. H.; Teng, A. P.; Nguyen, T. B.; Coggon, M. M.; Crounse, J. D.; St. Clair, J. M.; Zhang, X.; Schilling, K. A.; Seinfeld, J. $\mathrm{H}$.; Wennberg, P. O. Isoprene NO3 Oxidation Products from the RO2 + HO2 Pathway. J. Phys. Chem. A 2015, 119, 10158-10171.

(42) Eddingsaas, N. C.; Loza, C. L.; Yee, L. D.; Seinfeld, J. H.; Wennberg, P. O. $\alpha$-Pinene Photooxidation under Controlled Chemical Conditions - Part 1: Gas-Phase Composition in Low- and High-NOx Environments. Atmos. Chem. Phys. 2012, 12, 6489-6504.

(43) Lim, Y. B.; Ziemann, P. J. Effects of Molecular Structure on Aerosol Yields from $\mathrm{OH}$ Radical-Initiated Reactions of Linear, Branched, and Cyclic Alkanes in the Presence of NOx. Environ. Sci. Technol. 2009, 43, 2328-2334.

(44) Wängberg, I.; Barnes, I.; Becker, K. H. Product and Mechanistic Study of the Reaction of NO3 Radicals with $\alpha$-Pinene. Environ. Sci. Technol. 1997, 31, 2130-2135.

(45) Vereecken, L.; Peeters, J. A Structure-Activity Relationship for the Rate Coefficient of H-Migration in Substituted Alkoxy Radicals. Phys. Chem. Chem. Phys. 2010, 12, 12608.

(46) Atkinson, R. Rate Constants for the Atmospheric Reactions of Alkoxy Radicals: An Updated Estimation Method. Atmos. Environ. 2007, 41, 8468-8485.

(47) Vereecken, L.; Peeters, J. Decomposition of Substituted Alkoxy Radicals - Part I: A Generalized Structure-Activity Relationship for Reaction Barrier Heights. Phys. Chem. Chem. Phys. 2009, 11, 9062.

(48) Vereecken, L.; Peeters, J. A Theoretical Study of the OHInitiated Gas-Phase Oxidation Mechanism of $\beta$-Pinene (C10H16): First Generation Products. Phys. Chem. Chem. Phys. 2012, 14, 38023815.

(49) Vereecken, L.; Peeters, J. H-atom Abstraction by OH-Radicals from (Biogenic) (Poly)alkenes: $\mathrm{C}-\mathrm{H}$ Bond Strengths and Abstraction Rates. Chem. Phys. Lett. 2001, 333, 162-168.

(50) Kurtén, T.; Rissanen, M. P.; Mackeprang, K.; Thornton, J. A.; Hyttinen, N.; Jørgensen, S.; Ehn, M.; Kjaergaard, H. G. Computational Study of Hydrogen Shifts and Ring-Opening Mechanisms in $\alpha$-Pinene Ozonolysis Products. J. Phys. Chem. A 2015, 119, 11366-11375.

(51) Fry, J. L.; Kiendler-Scharr, A.; Rollins, A. W.; Brauers, T.; Brown, S. S.; Dorn, H. P.; Dubé, W. P.; Fuchs, H.; Mensah, A.; Rohrer, F.; Tillmann, R.; Wahner, A.; Wooldridge, P. J.; Cohen, R. C. SOA 
from Limonene: Role of NO3 in its Generation and Degradation. Atmos. Chem. Phys. 2011, 11, 3879-3894.

(52) Lee, L.; Teng, A. P.; Wennberg, P. O.; Crounse, J. D.; Cohen, R. C. On Rates and Mechanisms of $\mathrm{OH}$ and $\mathrm{O} 3$ Reactions with IsopreneDerived Hydroxy Nitrates. J. Phys. Chem. A 2014, 118, 1622-1637.

(53) Berndt, T.; Richters, S.; Jokinen, T.; Hyttinen, N.; Kurtén, T.; Otkjær, R. V.; Kjaergaard, H. G.; Stratmann, F.; Herrmann, H.; Sipilä, M.; Kulmala, M.; Ehn, M. Hydroxyl Radical-Induced Formation of Highly Oxidized Organic Compounds. Nat. Commun. 2016, 7, 13677.

(54) Eddingsaas, N. C.; Loza, C. L.; Yee, L. D.; Chan, M.; Schilling, K. A.; Chhabra, P. S.; Seinfeld, J. H.; Wennberg, P. O. $\alpha$-Pinene Photooxidation under Controlled Chemical Conditions - Part 2: SOA Yield and Composition in Low- and High-NOx Environments. Atmos. Chem. Phys. 2012, 12, 7413-7427.

(55) Griffin, R. J.; Cocker, D. R.; Flagan, R. C.; Seinfeld, J. H. Organic Aerosol Formation from the Oxidation of Biogenic Hydrocarbons. J. Geophys. Res.: Atmos. 1999, 104, 3555-3567.

(56) Halgren, T. A. MMFF VII. Characterization of MMFF94, MMFF94s, and other Widely Available Force Fields for Conformational Energies and for Intermolecular-Interaction Energies and Geometries. J. Comput. Chem. 1999, 20, 730-748.

(57) Spartan'14; Wavefunction, Inc.: Irvine, CA, 2014.

(58) Becke, A. D. Density-Functional Thermochemistry. III. The Role of Exact Exchange. J. Chem. Phys. 1993, 98, 5648-5652.

(59) Lee, C.; Yang, W.; Parr, R. G. Development of the Colle-Salvetti Correlation-Energy Formula into a Functional of the Electron Density. Phys. Rev. B: Condens. Matter Mater. Phys. 1988, 37, 785-789.

(60) Chai, J.-D.; Head-Gordon, M. Long-Range Corrected Hybrid Density Functionals with Damped Atom-Atom Dispersion Corrections. Phys. Chem. Chem. Phys. 2008, 10, 6615-6620.

(61) Dunning, T. H. Gaussian Basis Sets for use in Correlated Molecular Calculations. I. The Atoms Boron Through Neon and Hydrogen. J. Chem. Phys. 1989, 90, 1007-1023.

(62) Kendall, R. A.; Dunning, T. H.; Harrison, R. J. Electron Affinities of the First-Row Atoms Revisited. Systematic Basis Sets and Wave Functions. J. Chem. Phys. 1992, 96, 6796-6806.

(63) Frisch, M. J.; Trucks, G. W.; Schlegel, H. B.; Scuseria, G. E.; Robb, M. A.; Cheeseman, J. R.; Scalmani, G.; Barone, V.; Mennucci, B.; Petersson, G. A.; Nakatsuji, H.; Caricato, M.; Li, X.; Hratchian, H. P.; Izmaylov, A. F.; Bloino, J.; Zheng, G.; Sonnenberg, J. L.; Hada, M.; Ehara, M.; Toyota, K.; Fukuda, R.; Hasegawa, J.; Ishida, M.; Nakajima, T.; Honda, Y.; Kitao, O.; Nakai, H.; Vreven, T.; Montgomery, J. A., Jr.; Peralta, J. E.; Ogliaro, F.; Bearpark, M. J.; Heyd, J.; Brothers, E. N.; Kudin, K. N.; Staroverov, V. N.; Kobayashi, R.; Normand, J.; Raghavachari, K.; Rendell, A. P.; Burant, J. C.; Iyengar, S. S.; Tomasi, J.; Cossi, M.; Rega, N.; Millam, N. J.; Klene, M.; Knox, J. E.; Cross, J. B.; Bakken, V.; Adamo, C.; Jaramillo, J.; Gomperts, R.; Stratmann, R. E.; Yazyev, O.; Austin, A. J.; Cammi, R.; Pomelli, C.; Ochterski, J. W.; Martin, R. L.; Morokuma, K.; Zakrzewski, V. G.; Voth, G. A.; Salvador, P.; Dannenberg, J. J.; Dapprich, S.; Daniels, A. D.; Farkas, Ö.; Foresman, J. B.; Ortiz, J. V.; Cioslowski, J.; Fox, D. J. Gaussian 09, revision D.01; Gaussian, Inc.: Wallingford, CT, 2009.

(64) Eckart, C. The Penetration of a Potential Barrier by Electrons. Phys. Rev. 1930, 35, 1303-1309.

(65) Adler, T. B.; Knizia, G.; Werner, H.-J. A Simple and Efficient CCSD(T)-F12 Approximation. J. Chem. Phys. 2007, 127, 221106.

(66) Werner, H.-J.; Knowles, P. J.; Knizia, G.; Manby, F. R.; Schütz, M. Molpro: A General-Purpose Quantum Chemistry Program Package. Wiley Interdiscip. Rev.: Comput. Mol. Sci. 2012, 2, 242-253.

(67) Glowacki, D. R.; Liang, C.-H.; Morley, C.; Pilling, M. J.; Robertson, S. H. MESMER: An Open-Source Master Equation Solver for Multi-Energy Well Reactions. J. Phys. Chem. A 2012, 116, 95459560. 